Brit. J. industr. Med., 1965, 22, 285.

\title{
SILICOSIS FROM QUARRYING AND WORKING OF GRANITE
}

\author{
BY \\ A. AHLMARK, T. BRUCE, and Å. NYSTRÖM \\ From the National Institute of Public Health, Department of Industrial Health, Stockholm, \\ Söderby Chest Hospital, Ultran, and Södersjukhuset, Department of Industrial Medicine, Stockholm
}

(RECEIVED FOR PUBLICATION JANUARY 13, 1965)

Previous knowledge of silicosis in the Swedish granite industry suggested that the disease was neither common nor severe. In recent years, however, changes in working methods have involved a considerably increased formation of dust, and it was considered likely that the risk of contracting silicosis was increased. Reports from other countries supported this conjecture.

The 34 known cases of silicosis caused by quarrying and working of granite in Sweden were therefore reviewed. The mean duration of exposure to siliceous dust when stage I silicosis was diagnosed was 32 years, and the mean age at diagnosis was 55 years. Despite the relatively long 'prediagnosis' exposure to dust, the disease showed a pronounced tendency to progression, and six cases were complicated by pulmonary tuberculosis. Eighty per cent of the men were awarded disablement benefit because of their pulmonary lesions, and four men died from silicosis alone or in combination with tuberculosis.

In Swedish granite works there is room for considerable improvement in dust suppression. Careful checks of such preventive measures and periodic medical examination of exposed persons are strongly advocated.

\section{Technical Background}

Granite is composed mainly of feldspar and quartz.* The content of free silica may range from 10 to $40 \%$, but in marketable Swedish granite it is usually about $35 \%$. In Sweden, as elsewhere, granite is extensively used for paving and for building wharves, bridges, pillars, monuments, etc. Quarrying and working of granite have a long history in this country. In the latter part of the eighteenth century the State owned and worked fairly large granite quarries in southern Sweden. About the middle of the following century new quarries were opened up in many coastal regions of central and southern Sweden.

All Swedish granite is cut from open quarries and much of the working of the stone is done in the open

* Granite and gneiss comprise part of the masses of igneous rock that cover much of Scandinavia, Finland, and the Kola peninsula. Granite occurs also in many parts of Germany, Italy, Scotland, North America, and other countries.

+Detailed information on the number of persons employed in the Swedish granite industry is not available. According to a spokesman for the industry, however, about 200 men are engaged in particularly dusty work and they are exposed to the dust for on average 30 to $40 \%$ of their total working time (Egerlund, 1964). air near the quarries. Because of this, little attention has been paid to silicosis in the Swedish granite industry in the past, even though the industry at times has employed many persons. $\uparrow$ In the past 20 to 25 years, however, changes in the methods of cutting and working stone seem to have increased considerably the risk of dust disease. The replacement of hammer and chisel by pneumatic tools tends to increase the amount of dust raised in various processes. Mechanization requires fixed working areas, many of which have been partly or completely enclosed, and this again has led to increased contamination of the atmosphere. In Sweden and in other countries, attempts have been made to counteract these health risks, and it seems feasible to effect a considerable reduction of dust in the granite works (for references cf. Öhman, 1953).

Developments in the granite industry have been similar in other countries. In many places, however, the stone has traditionally been dressed in enclosed workshops, and in some countries mechanical processes were introduced much earlier than in Sweden. This probably explains the gravity of some reports of silicosis due to granite dust. 


\section{Earlier Observations on Risk of Silicosis from Granite}

Assessments of the risk of silicosis from quarrying and working of granite vary in the literature. Probable reasons for this conflict of opinions include differences in working methods and in the content of free crystalline silica in the rock. Koelsch and Kaestle (1929) found silicosis in only a few granite workers, and even after many years of exposure to dust the lesions seldom reached stage II. Röhrl (1947) studied more than 4,100 persons variously employed in the granite industry in Saxony, Bavaria, and Austria and found that slightly more than $8 \%$ had silicosis. In most cases there was a long history of dust exposure, averaging 33 years in stage I silicosis, 36 years in stage II, and 45 years in stage III. Only about $1 \%$ had stage III lesions; $6 \%$ had stage II. Sutherland, Bryson, and Keating (1930) reported that $17 \%$ of a fairly large number of British workers in granite had silicosis. Several other writers (Hoffman, 1922; Russell, Britten, Thompson, and Bloomfield, 1929) stated that silicosis was common among granite cutters in North America and not infrequently was accompanied by tuberculosis. The increased incidence of silicosis that has been registered among American granite workers has been ascribed mainly to intensification of dust following mechanization of the industry.

In the Swedish granite industry silicosis has not previously been an important problem. When Bruce (1942) made his nation-wide survey of pneumoconiosis at the end of the 1930s, no case of silicosis was known among granite workers. In our review of pneumoconiosis in Sweden some 20 years later, we found that 11 persons had contracted the disease from quarrying and working of granite (Ahlmark, Bruce, and Nyström, 1960a). Most of them were between 50 and 60 years old at the time of diagnosis. The disease was mild (stage $I$ in 10 cases) and showed little tendency to progress during the observation period (in a single case from stage I to stage $\mathrm{II}^{*}$ ). The duration of exposure to granite dust ranged from 21 to 50 years, average about 35 years.

Tuberculosis complicated silicosis in only one of the 11 cases. Four men died during the follow-up period, one of them of silicosis and one of silicosis plus tuberculosis. The ages at death were 50,66, 67, and 82 years. Nine of the 11 men were legally eligible for compensation according to the regulations then in force. Only three of these nine were classified as disabled, and compensation rates ranged from 10 to $75 \%$.

*This man had done granite quarrying and dressing in America for 15 years prior to 1920 . Subsequently he was employed in Sweden for more than 20 years and during that time was exposed to fairly high concentrations of granite dust.
From these medical findings it was inferred that silicosis due to quarrying and working of granite in this country was neither particularly frequent nor severe. We remarked, however, that recent technical changes, which had accentuated the problem of granite dust, might have made the situation more serious than was indicated by our review, and that such a possibility was suggested by observations in other countries. Intensification of dust suppression with adequate control monitoring were therefore recommended. Compulsory medical supervision was proposed.

An investigation of silicosis in granite workers in Bohus County in Sweden was subsequently published by Forsgren (1963). He reported silicosis in $28 \mathrm{men}$, most of whom had co-existent tuberculosis. Eight men with silicosis and tuberculosis had died; the age at death was about 70 years. Forsgren expressed the opinion that granite-workers' silicosis previously had run a benign course, leaving the working capacity unimpaired in old age, but that it had now become a more serious disorder, chiefly due to the increased use of dust-producing machinery. He pleaded for energetic measures to combat the inhalation of noxious dust, periodic medical examination of exposed workers, and a change of occupation when incipient silicosis was found on radiography.

\section{The Current State of Silicosis}

Since we completed our general review of pneumoconiosis in Sweden (Ahlmark et al., 1960a), 23 more cases of silicosis among persons engaged in quarrying and working of granite have been notified to the insurance authorities. Including the 11 cases earlier described by us, therefore, 34 cases of silicosis from this cause are now officially known in Sweden. $\dagger$ The true number of cases may well be greater, however, since neither periodic medical examination nor notification of silicosis is compulsory in the industry. Moreover, experience from other occupational groups has shown that, for various reasons, many cases of pneumoconiosis are not notified to the insurance authorities until several years after the first 'positive' radiographs.

In the 34 known cases of silicosis in quarriers and dressers of granite, the dates of the first films showing silicosis were as follows.

$\begin{array}{cc}\text { Year } & \text { No. of Cases } \\ -1945 & 4 \\ 1946-1950 & 3 \\ 1951-1955 & 12 \\ 1956-1960 & 11 \\ 1961- & 4\end{array}$

† Since we concluded this investigation, five more cases of silicosis have been reported in granite workers. In four cases the disease has reached stage II, and in the fifth stage III lesions are present. 


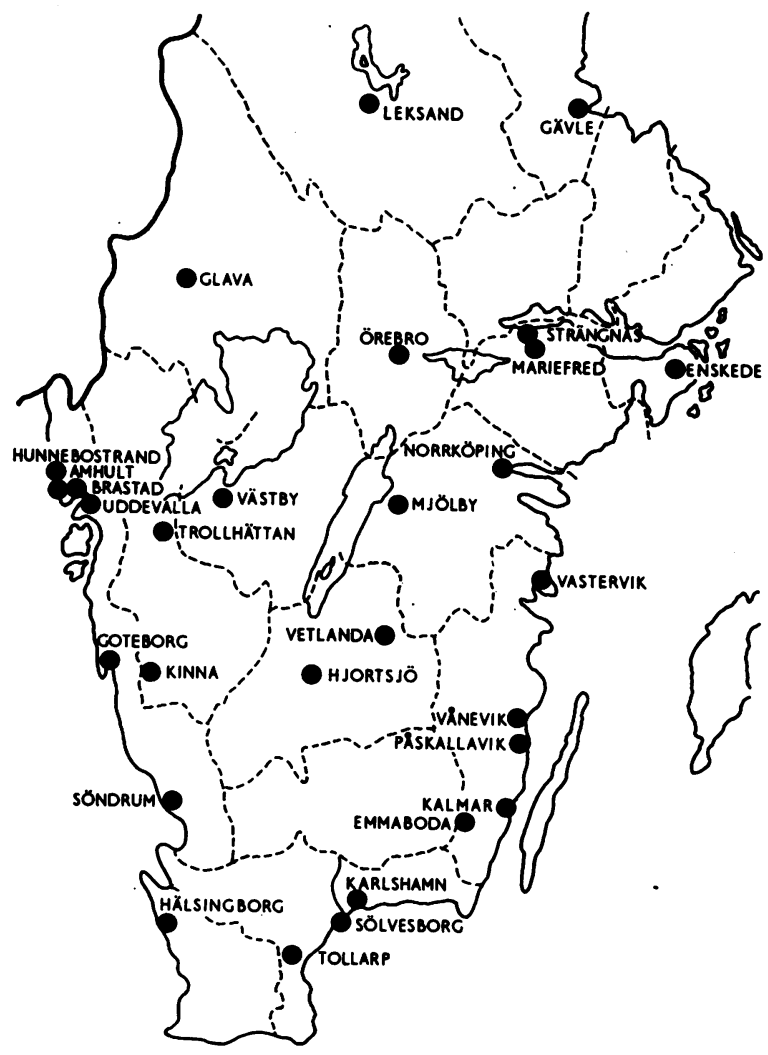

FIG. 1.-Map of central and southern Sweden showing 29 places in which silicosis was contracted from quarrying and working of granite.

TABLE 1

SEVERITY OF GRANITE WORKERS' SILICOSIS AT DIAGNOSIS IN DIFFERENT PERIODS

\begin{tabular}{l|r|c|c|c}
\hline \multirow{2}{*}{$\begin{array}{c}\text { Time of } \\
\text { Diagnosis }\end{array}$} & \multicolumn{3}{|c|}{ Stage of Silicosis } & Total \\
\cline { 2 - 4 } & I & II & III & \\
\hline $1931-40$ & 3 & - & - & 3 \\
$1941-50$ & 2 & 4 & 1 & 23 \\
$1951-60$ & 18 & 4 & - & 4 \\
$1961-63$ & 3 & 1 & 2 & 34 \\
\hline Total & 26 & 6 & 2 \\
\hline
\end{tabular}

TABLE 2

AGE OF GRANITE WORKERS AT DIAGNOSIS OF SILICOSIS

\begin{tabular}{l|r|c|c|c}
\hline \multirow{2}{*}{ Age (years) } & \multicolumn{3}{|c|}{ Stage of Silicosis } & Total \\
\cline { 2 - 3 } & I & II & III & \\
\hline $31-40$ & 1 & - & - & 1 \\
$41-50$ & 6 & - & - & 6 \\
$51-60$ & 14 & 4 & 1 & 19 \\
$61-70$ & 5 & 2 & 1 & 8 \\
\hline Total & 26 & 6 & 2 & 34 \\
\hline
\end{tabular}

Because of the delay in notification of silicosis noted above, it is probable that more cases will ultimately be added to this total, particularly those diagnosed after 1955.

The 34 silicotic granite workers had been exposed to dust in about 50 workplaces. In 18 cases the employment records showed two or more firms (one man had worked in seven places). The remaining 16 men had contracted silicosis in one of 13 granite works. Figure 1 shows the geographical distribution of granite works which could be ascertained from insurance notes.

The stage of silicosis on the first 'positive' radiograph is shown in Table 1 . During the period covered by the study there was no clear tendency for change in the severity of the lesions at diagnosis. The age of the affected men at the time of diagnosis is shown in Table 2; 27 of the 34 men were more than 50 years old.

Particularly important in assessing the severity of exposure to dust is the duration of exposure before the detection of silicosis. In these cases the period of 'prediagnosis' dust exposure (Table 3 ) averaged 30

TABLE 3

DURATION OF EXPOSURE TO GRANITE DUST AT DIAGNOSIS OF SILICOSIS

\begin{tabular}{|c|c|c|c|c|}
\hline \multirow{2}{*}{$\underset{\text { (years) }}{\text { Exposure }}$} & \multicolumn{3}{|c|}{ Stage of Silicosis } & \multirow{2}{*}{ Total } \\
\hline & I & II & III & \\
\hline $\begin{array}{r}-10 \\
11-20 \\
21-30 \\
31-40 \\
41-50 \\
51-\end{array}$ & $\begin{array}{r}1 \\
1 \\
7 \\
13 \\
3 \\
1\end{array}$ & $\begin{array}{l}\bar{Z} \\
2 \\
2 \\
2 \\
-\end{array}$ & $\begin{array}{l}\overline{1} \\
\frac{1}{-}\end{array}$ & $\begin{array}{r}1 \\
1 \\
10 \\
16 \\
5 \\
1\end{array}$ \\
\hline Total & 26 & 6 & 2 & 34 \\
\hline
\end{tabular}

to 35 years. In the case with the shortest period (six years) the exposure to dust ceased in 1930 and silicosis was not found until 1951. The lesions were then classified as stage I-II, but in 1959 there was progression to stage II-III. The longest exposure period (52 years) preceded the detection of stage I silicosis in a man who had worked with granite since the age of 17 years.

Shortening or lengthening of the 'prediagnosis' exposure to dust during the time covered by our investigation could have reflected a change in the severity of exposure. The series of cases was therefore divided into two equal parts according to the year of diagnosis. Table 4 shows that the duration of exposure tended to be longer among the latest diagnosed cases. But, as stage II silicosis was more common in this group, the observed difference in the duration of exposure could not be given any clear significance. 
TABLE 4

LENGTH OF PREDIAGNOSTIC DUST EXPOSURE IN CASES OF SILICOSIS DIAGNOSED 1929-53 AND 1953-62

\begin{tabular}{|c|c|c|c|c|c|c|}
\hline \multirow{2}{*}{$\begin{array}{l}\text { Exposure } \\
\text { (years) }\end{array}$} & \multicolumn{3}{|c|}{$\begin{array}{c}\text { Stage of Silicosis } \\
\text { Diagnosed 1929-53 }\end{array}$} & \multicolumn{3}{|c|}{$\begin{array}{l}\text { Stage of Silicosis } \\
\text { Diagnosed 1953-62 }\end{array}$} \\
\hline & I & II & III & I & II & III \\
\hline $\begin{array}{r}-10 \\
11-20 \\
21-30 \\
31-40 \\
41-50 \\
51-\end{array}$ & $\begin{array}{r}1 \\
4 \\
8 \\
1 \\
-\end{array}$ & $\begin{array}{l}\frac{7}{2} \\
\bar{z}\end{array}$ & $\frac{z}{\overline{1}}$ & $\begin{array}{l}\overline{1} \\
3 \\
5 \\
2 \\
1\end{array}$ & $\frac{\bar{Z}}{\frac{7}{2}}$ & $\begin{array}{l}\overline{1} \\
\bar{z}\end{array}$ \\
\hline Total & 14 & 2 & 1 & 12 & 4 & 1 \\
\hline
\end{tabular}

Figure 2 shows the periods during which the individual workers were exposed to granite dust. It is seen that the exposure was predominantly distant in time, almost half of it before 1935. In the cases which were diagnosed during the past decade, however, most of the exposure occurred after 1940-45.

In six cases silicosis was complicated by tuberculosis. These cases are reviewed in Table 5. The age range when silicosis was detected was 42 to 66 years. Three of these men died during the observation period.

The total number of deaths among the 34 men is now six. Four deaths were due to silicosis alone or in association with tuberculosis.

The tendency of silicosis to progress after diagnosis is another indicator of the severity of exposure to dust (Ahlmark et al., 1960b; Ahlmark and Glömme, 1962). Table 6 shows the 32 cases in which serial radiographs were available. It is seen that 18 of the 30 cases of stage I or stage II silicosis showed progression during the observation period.

Table 7 shows the latest assessments of disablement due to dust disease. Under Swedish law no compensation is payable when disablement is less than $10 \%$. Twenty-six men were awarded statutory compensation. The eight cases in which assessment was more than $75 \%$ included men who were receiving full sickness benefit because of concomitant tuberculosis.

\section{Comparison with Pneumoconiosis in Other Occupations}

In order to compare the silicosis in these granite workers with more extensively studied forms of dust disease, we used some data from our general survey of pneumoconiosis in Sweden (Ahlmark et al., 1960a). It should be noted that in every case the disease was contracted solely in the mentioned occupation.

Table 8 shows the age at which exposure to dust began, the mean duration of exposure prior to diagnosis of early pneumoconiosis, and the mean age at the time of diagnosis. It is seen that, whereas most pottery forming-shop workers and iron-ore drillers were less than 20 years old when they were first exposed to siliceous dust, sand blasters, steel fettlers, and quartz crushers were considerably older. The granite workers were among the groups whose exposure began at a relatively early age.

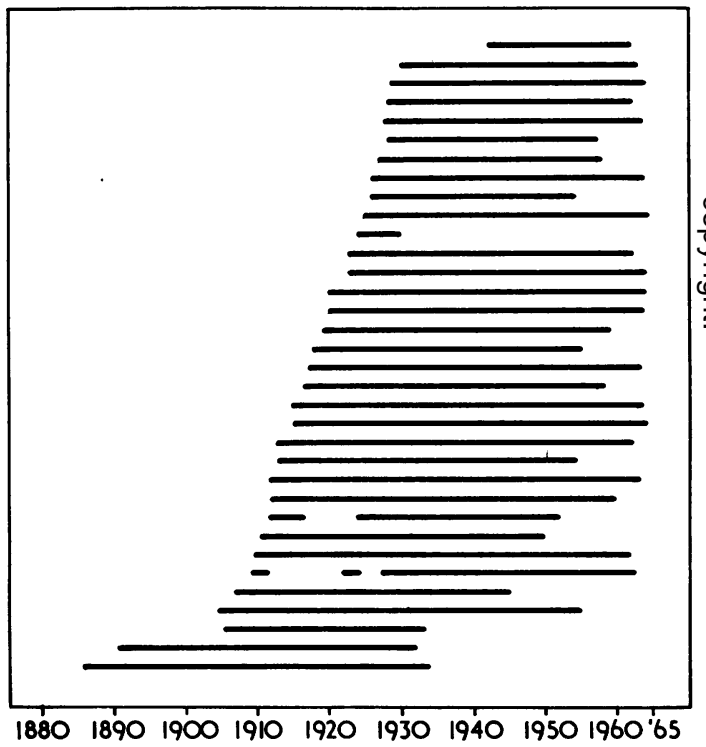

FIG. 2.-Time during which the 34 silicotic granite workers were exposed to the causal dust. Each line represents a single worker.

TABLE 5

TUBERCULOSIS COMPLICATING SILICOSIS IN GRANITE WORKERS

\begin{tabular}{|c|c|c|c|c|c|c|}
\hline \multirow{2}{*}{$\underset{\text { (years) }}{\text { Exposure }}$} & \multicolumn{2}{|c|}{ Silicosis Stage at Diagnosis of } & \multicolumn{2}{|c|}{ Age (years) at Diagnosis of } & \multirow{2}{*}{ Age at Death } & \multirow{2}{*}{ Year of Death } \\
\hline & Silicosis & $\begin{array}{c}\text { Pulmonary } \\
\text { Tuberculosis }\end{array}$ & Silicosis & $\begin{array}{l}\text { Pulmonary } \\
\text { Tuberculosis }\end{array}$ & & \\
\hline $\begin{array}{l}38 \\
49 \\
46 \\
33 \\
24 \\
30\end{array}$ & $\begin{array}{c}\text { I } \\
\text { I-II } \\
\text { II } \\
\text { I } \\
\text { I } \\
\text { II-III }\end{array}$ & $\begin{array}{c}\text { II } \\
\text { IIII } \\
\text { II } \\
\text { II } \\
\text { I } \\
\text { III }\end{array}$ & $\begin{array}{l}59 \\
66 \\
61 \\
58 \\
42 \\
57\end{array}$ & $\begin{array}{l}63 \\
66 \\
62 \\
64 \\
49 \\
63\end{array}$ & $\begin{array}{l}\bar{Z} \\
\overline{65} \\
50 \\
66\end{array}$ & $\begin{array}{l}\bar{z} \\
\overline{1963} \\
1937 \\
1960\end{array}$ \\
\hline
\end{tabular}


TABLE 6

PROGRESSION OF SILICOSIS IN GRANITE WORKERS

\begin{tabular}{|c|c|c|c|c|c|}
\hline \multicolumn{2}{|c|}{ First Radiograph } & \multicolumn{3}{|c|}{$\begin{array}{c}\text { Stage of Silicosis on Latest } \\
\text { Radiograph }\end{array}$} & \multirow{2}{*}{ Total } \\
\hline $\begin{array}{l}\text { Stage of } \\
\text { Silicosis }\end{array}$ & $\begin{array}{l}\text { No. of } \\
\text { Cases }\end{array}$ & I & II & III & \\
\hline $\begin{array}{l}\text { I } \\
\text { III }\end{array}$ & $\begin{array}{c}26 \\
6^{*} \\
2\end{array}$ & $\frac{10}{二}$ & $\begin{array}{r}14 \\
2 \\
-\end{array}$ & $\begin{array}{l}2 \\
2 \\
2\end{array}$ & $\begin{array}{c}26 \\
4^{*} \\
2\end{array}$ \\
\hline Total & 34 & 10 & 16 & 6 & 32 \\
\hline
\end{tabular}

*In two cases no later radiograph.

TABLE 7

DISABLEMENT BENEFIT AWARDED TO GRANITE WORKERS ON LATEST ASSESSMENT

\begin{tabular}{|c|c|c|c|c|}
\hline \multirow{2}{*}{$\begin{array}{l}\text { Disable- } \\
\text { ment (\%) }\end{array}$} & \multicolumn{3}{|c|}{ Stage of Silicosis } & \multirow{2}{*}{ Total } \\
\hline & I & II & III & \\
\hline $\begin{array}{l}<10 \\
10-25 \\
26-50 \\
51-75 \\
76-100\end{array}$ & $\begin{array}{l}4 \\
2 \\
1 \\
1 \\
1\end{array}$ & $\begin{array}{l}3 \\
5 \\
5 \\
1 \\
4\end{array}$ & $\begin{array}{c}\overline{-} \\
2 \\
1 \\
3\end{array}$ & $\begin{array}{l}7 \\
7 \\
8 \\
3 \\
8\end{array}$ \\
\hline Total & 9* & 18 & 6 & 33 \\
\hline
\end{tabular}

* In one case compensation was refused on legal grounds.

The duration of exposure to dust prior to diagnosis was seldom more than 20 years in the steel fettlers and as a rule it was about 10 years. In the pottery forming-shop workers and the iron-ore drillers this period averaged about 20 years. The longest 'prediagnosis' exposure periods (generally more than 30 years) were found in coal miners and iron moulders. In the granite workers the mean length of the corresponding period was 32 years. One must keep in mind, however, that the length of this period of dust exposure is dependent inter alia on the regularity of radiological examination. In contrast to other occupational categories, regular medical observation for pneumoconiosis has not been comprehensively enforced among iron moulders and granite workers.

Since the age at commencing exposure to dust was lower in occupations with long 'prediagnosis' exposure and higher in occupations with shorter exposure, the age at diagnosis of pneumoconiosis was similar in the various groups. The mean age ranged from 43 to 55 years (Table 8). The mean age of the granite workers at diagnosis was 55 years. Whether this was because these men inhaled relatively little dust per unit of time, or because they did not have regular radiological follow-up, could not be reliably judged from our case material.

Table 9 provides a rough estimate of progression in pneumoconiosis. The observation periods varied but were in most cases about eight to 12 years. In most of the granite workers the initial films showed stage I. Only the coal miners and the iron moulders had a higher percentage of cases with early lesions. The granite workers' disease nevertheless showed a strong tendency to progression. Whereas the frequency of progression of coal miners' and iron moulders' pneumoconiosis was only $3 \%$ and $10 \%$, respectively, the corresponding figure for the quarriers and dressers of granite was $60 \%$. One reason may have been the higher frequency of coexistent pulmonary tuberculosis among the granite workers. Another possible cause is that 21 of the 34 granite workers continued in the same occupation after silicosis had been found. This was a higher figure than in many of the other occupational groups.

A more detailed comparison between the course of pneumoconiosis in the granite workers and that in iron moulders and steel fettlers is presented in Figure 3. The figures for the two latter categories are taken from an earlier report (Ahlmark and Glömme, 1962). Progression of pneumoconiosis was as rapid in the granite workers as in the steel fettlers, but the mortality during the first five years after diagnosis was lower in the former group, which implies that advanced disease was somewhat less common. Iron moulders' pneumoconiosis ran a much more benign course.

Thus, although in silicosis, contracted from

TABLE 8

PNEUMOCONIOSIS IN VARIOUS OCCUPATIONAL GROUPS: AGE AT COMMENCING DUST EXPOSURE, DURATION OF EXPOSURE, AND AGE AT DIAGNOSIS

\begin{tabular}{|c|c|c|c|c|c|c|}
\hline \multirow[t]{2}{*}{ Occupation } & \multirow{2}{*}{ No. of Cases } & \multicolumn{3}{|c|}{$\begin{array}{l}\text { Age (years) at Commencement of Exposure } \\
\text { to Dust (in \% of Group) }\end{array}$} & \multirow{2}{*}{$\begin{array}{c}\text { Mean Exposure } \\
\text { (years) at } \\
\text { Diagnosis of } \\
\text { Stage I } \\
\text { Silicosis }\end{array}$} & \multirow{2}{*}{$\begin{array}{c}\text { Mean Age at } \\
\text { Diagnosis } \\
\text { (years) }\end{array}$} \\
\hline & & $\leqslant 20$ & $21-40$ & $>40$ & & \\
\hline $\begin{array}{l}\text { Coal miner } \\
\text { Iron moulder } \\
\text { Iron-ore driller } \\
\text { Steel furnace mason and steel moulder } \\
\text { Sand blaster and sandstone grinder } \\
\text { Quartz crusher } \\
\text { Pottery forming-shop worker } \\
\text { Steel fettler }\end{array}$ & $\begin{array}{r}35 \\
203 \\
348 \\
165 \\
58 \\
78 \\
125 \\
84\end{array}$ & $\begin{array}{r}60 \\
24 \\
73 \\
57 \\
10 \\
6 \\
80 \\
12\end{array}$ & $\begin{array}{l}40 \\
73 \\
24 \\
41 \\
80 \\
52 \\
19 \\
78\end{array}$ & $\begin{array}{r}-3 \\
3 \\
2 \\
10 \\
42 \\
1 \\
10\end{array}$ & $\begin{array}{l}38 \\
34 \\
19 \\
23 \\
12 \\
9 \\
23 \\
12\end{array}$ & $\begin{array}{l}55 \\
47 \\
50 \\
52 \\
48 \\
50 \\
43 \\
45\end{array}$ \\
\hline Granite quarrier and dresser & 34 & 59 & 41 & & 32 & 55 \\
\hline
\end{tabular}


TABLE 9

COURSE OF PNEUMOCONIOSIS AND FREQUENCY OF CO-EXISTENT TUBERCULOSIS IN VARIOUS OCCUPATIONAL GROUPS

\begin{tabular}{|c|c|c|c|c|c|}
\hline \multirow{2}{*}{ Occupation } & \multicolumn{3}{|c|}{ Stage of Pneumoconiosis at Diagnosis ( $\%$ of group) } & \multirow{2}{*}{$\begin{array}{l}\text { Frequency of } \\
\text { Progression } \\
\text { (\% of group) }\end{array}$} & \multirow{2}{*}{$\begin{array}{l}\text { Frequency of } \\
\text { Tuberculosis } \\
\text { ( } \% \text { of group) }\end{array}$} \\
\hline & I & II & III & & \\
\hline $\begin{array}{l}\text { Coal miner } \\
\text { Iron moulder } \\
\text { Iron-ore driller } \\
\text { Steel furnace mason and steel moulder } \\
\text { Sand blaster and sandstone grinder } \\
\text { Quartz crusher } \\
\text { Pottery forming-shop worker } \\
\text { Steel fettler }\end{array}$ & $\begin{array}{l}85 \\
91 \\
70 \\
64 \\
45 \\
43 \\
62 \\
70\end{array}$ & $\begin{array}{r}9 \\
8 \\
20 \\
22 \\
34 \\
27 \\
24 \\
19\end{array}$ & $\begin{array}{r}6 \\
1 \\
10 \\
14 \\
21 \\
30 \\
14 \\
11\end{array}$ & $\begin{array}{r}3 \\
10 \\
27 \\
36 \\
50 \\
53 \\
56 \\
56\end{array}$ & $\begin{array}{r}0 \\
2 \\
9 \\
11 \\
18 \\
15 \\
9 \\
12\end{array}$ \\
\hline Granite quarrier and dresser & 76 & 18 & 6 & 60 & 18 \\
\hline
\end{tabular}

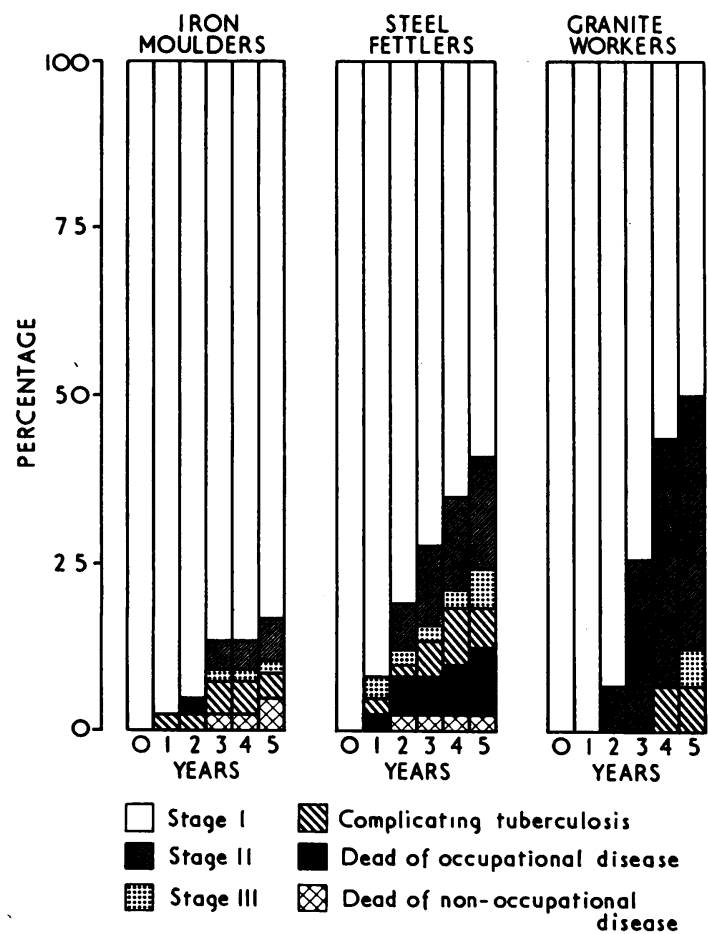

FIG. 3.-Progression of pneumoconiosis in 46 iron moulders, 38 stee fettlers, and 16 granite workers with serial radiographs during the first five years after diagnosis. quarrying and working of granite, the duration of exposure to dust and the age at diagnosis approximated to the figures in the relatively benign pneumoconioses of coal miners and iron moulders, the granite workers' disease showed a strong tendency to progression. In this respect silicosis from quarrying and working of granite was comparable with silicosis in quartz crushers and steel fettlers. Presumably, therefore, the concentrations of airborne quartz dust were higher in the granite works than in the coal mines and iron moulding shops.

\section{REFERENCES}

Ahlmark, A., Bruce, T., and Nyström, §. (1960a). Silicosis and Other Pneumoconioses in Sweden. Scandinavian University Books,

$\longrightarrow, \frac{\text { Stockholm. }}{\text { p. }}$ (1960b). Proc. 13th int. Congr. Occup. Health, and Glömme, J. (1962). Industr. Med. Surg., 31, 517.

Bruce, T. (1942). Die Silikose als Berufskrankheit in Schweden. Eine klinische und gewerbedmedizinische Studie. Acta med.scand., 110, Suppl. 129.

Egerlund, R. (1964). Personal communication.

Forsgren, E. (1963). Svenska Läk.-Tidn., 60, 2003.

Hoffman, F. L. (1922). The problem of dust phthisis in the granitestone industry. Bureau of Labor Statistics, Washington, no. 293, VI, 178 p.

Koelsch, F., and Kaestle, K. (1929). Arbeitsmedizinische Untersuchungen über die Wirkungen verschiedener Mineralstau bArten. Beil. Reichsarbeitsblatt T. III, 26, 52 .

Öhman, H. (1953). Tidskr. Arbetarskyddet, no. 6.

Russell, A. E., Britten, R. H. Thompson, L. R., and Bloomfield, J. J. (1929). The Health of Workers in Dusty Trades. II. Exposure to Siliceous Dust (Granite Industry). Publ. Hlth Bull. (Wash.) to Siliceo

Röhrl, W. (1947). Die Granit-Silikose. Arbeitsmedizin, no. 23.

Sutherland, C. L., Bryson, S., and Keating, N. (1930). Report on the occurrence of Silicosis amongst granite workers. Home Office Report, 1930, 34-208. 